\title{
ESTIMATING A POVERTY LINE: An application to free basic municipal services in South Africa
}

\author{
DEVELOPMENT POLICY RESEARCH UNIT \\ HAROON BHORAT \\ Development Policy Research Unit \\ haroon.bhorat@uct.ac.za \\ MORNE OOSTHUIZEN \\ Development Policy Research Unit \\ Morne.Oosthuizen@uct.ac.za

\section{CARLENE VAN DER WESTHUIZEN} \\ Development Policy Research Unit \\ Carlene.vanderWesthuizen@uct.ac.za
}

ISBN 978-1-920055-83-7

October 2011

(C) University of Cape Town 2012 


\section{ABSTRACT}

One of the key interventions aimed at improving the welfare of South African households has been local government's provision of a package of free basic services (FBS) to poor households. It is, however, not completely clear how different municipalities identify households which are eligible for FBS. Evidence suggests that many municipalities currently provide services to all households with a monthly income of less than R1500 per month. This "FBS poverty line" is, however, low in comparison with a number of unofficial poverty lines utilised by policymakers and researchers in South Africa. This paper considers the impact of increasing the value of the FBS line, both in terms of the additional share and number of households eligible for support as well as the additional financial cost. We find that urban municipalities will face the steepest increases in their FBS budgets with any potential increase in the FBS poverty line.

KEYWORDS: free basic services, poverty line, municipal services, South Africa 


\section{CONTENTS}

1. INTRODUCTION 


\section{INTRODUCTION}

The eradication of poverty is one of the key priorities for the government and various other sectors of South African society. As part of this attempt, government has instituted a range of policy interventions designed to improve the welfare of households. These include significant increases in the delivery of services including formal dwellings, piped water, sanitation and electricity. Indeed, data for the period 1993-2005 indicates significant increases in the delivery of all these public assets to poor households. Paralleling these deliverables has been a focus within local government to deliver a basic package of free municipal services to poor households. Currently these run the ambit of free basic water ( $6 \mathrm{kl}$ per household per month), free basic electricity (50kWh per household per month), free basic sanitation and refuse removal.

However, one of the critical areas which remain somewhat opaque is how a municipality defines a poor household. At present, households are required to complete an application form to assess their status as an indigent household. Implicit then in this procedure, is a presumption that poor households can be separated from non-poor households. Current evidence indicates that households with an income below R1500 per month are eligible for the Free Basic Service (FBS) package. This is effectively a decision taken around where to set a household poverty line for South Africa. Put differently, there is an in-built assumption that the R1500 'FBS poverty line' is a suitable and generally acceptable poverty line and that households below that line are deemed to be poor and eligible for FBS.

The purpose of this paper is four-fold: Firstly, to briefly outline the standard, internationally acceptable methodologies utilised to derive a poverty line. Secondly, whilst there is no official poverty line sanctioned by government for South Africa, we present a number of unofficial poverty lines which have been utilised by researchers and policymakers. Thirdly, we compare the FBS poverty line against the eligibility tests for other indigency-linked services offered by government, focusing in particular on the different social grants. Finally, the paper tries to model, in a very basic manner, the potential number of households eligible for FBS when assuming different values of an FBS poverty line and attempts to provide some estimates of the possible financial implication of alternative lines.

\section{ESTIMATING A POVERTY LINE: APPROACHES AND SOME KEY ISSUES}

There are three basic approaches in estimating poverty lines, namely an absolute, a relative and a subjective approach, each of which views poverty, the experience of poverty and its most appropriate quantification differently (Ravallion, 1992). The absolute approach to poverty measurement constructs a line that values in monetary terms the goods and services required to meet a set of absolute minimum living standards across various basic needs of individuals and households. The value of an absolute poverty line is fixed in real terms, with the only changes to the monetary value being adjustments to take account of inflation. In contrast, a relative poverty line is not anchored around minimum living standards or basic needs. Instead, it takes into account a given society's characteristics and attempts to identify those individuals whose standards of living are unacceptably low relative to the rest of society. Such a poverty line begins to measure the ability of households or individuals to engage adequately in their society and is often defined as a proportion of the mean or median income or expenditure. Finally, the subjective approach to poverty measurement relies on individuals' opinions as to what constitutes the minimum income or expenditure required by a household.

The choice of the approach to estimating a poverty line is not the only issue to consider when measuring poverty. Much has been written on the choice between expenditure and income as the optimal measure of welfare (see for example Chaudhuri \& Ravallion, 1994; Deaton, 1997), but ultimately the choice is driven by the availability and quality of data in any individual country. A second issue relates to household size and structure. It is reasonable to expect that larger households have some level of 'cost advantage' over smaller households. In other words, there are economies of scale in consumption to the extent that larger households can attain the same level of welfare on a lower per capita expenditure amount than smaller households. 
In addition, age and gender may impact on household members' relative consumption levels. Thus, for example, infants and children would consume substantially less than would adults. In terms of the implications for poverty measurement, a household comprising four adults is arguably worse off than a household consisting of one adult and three small children even though the two households have the same level of expenditure. In order to account for this, equivalence scales are utilised, assigning adult equivalent values to the children in a household (e.g. a child equalling 0.75 or 0.5 adults) (Oosthuizen, 2008).

Theoretically, these two issues are very important for policy analysis since neglecting to correct for them may result in a misidentification of households and individuals as poor when they are non-poor and vice versa. However, in terms of poverty profiling, these issues may or may not be that serious and, therefore, there may be insufficient justification for the computational complexity that these adjustments entail. Woolard and Leibbrandt (2005) investigate the impact that varying assumptions on equivalence scales (a child equalling 1.0, 0.75 or 0.5 adults) have on the incidence of poverty for various groups and find that the choice of equivalence scale makes little difference to the ultimate identification of vulnerable households and the final poverty estimates derived.

\section{POVERTY LINES FOR SOUTH AFRICA}

Currently no official poverty line exists for South Africa and policymakers, researchers and other institutions utilise a range of unofficial poverty lines to measure the incidence, depth and severity of poverty in South Africa. A selection of these lines is presented in Table 1 in 2008 prices (The original poverty line values are found in Appendix 1). Where the original poverty line is a per capita poverty line, a household poverty line is estimated by multiplying the per capita line by the average household size (3.8 people) as recorded in the 2005/2006 Income and Expenditure Survey (Statistics South Africa, 2008). Column four provides an indication of how the values of the various household poverty lines compare with the R1500 FBS poverty line.

The Minimum Living Level (MLL) and Subsistence Living Level (SLL) are derived by the Bureau for Market Research, in Pretoria, South Africa (BMR,2002)1. Both are estimated through BMR's in-house surveys of South Africa's major cities and selected urban areas. Herein lies a key drawback of these poverty lines -they exclude the rural areas of South Africa where a disproportionate share of South Africa's poor, and in particular the ultra-poor, is located. A second worrying facet of these poverty line estimates is that they are race-based and continue to present the MLL and SLL estimates according to, for example, a 'black family of six in a township'. Apart from being morally questionable, this approach is highly problematic in empirical terms. The point of departure for deriving a poverty line of any form is to examine the entire distribution of income or consumption, irrespective of social or racial category.

It should be noted that the various annual estimates for the MML and the SLL are not readily available and we have to rely on secondary sources for estimates of these lines. When the values of the MLL and SLL from 1993 (Woolard and Leibbrandt, 2001) are inflated using the Consumer Price Index, household poverty lines of R1631 and R2186 are derived. These values correspond to 109 and 146 percent respectively of the FBS poverty line value.

More recent estimates of the MML sourced from Landman (2003) and Martins (2003) yield higher household poverty lines for 2008. Landman (2003) utilises a household poverty line for a household of four people. Adjusted for the impact of inflation, this MLL is approximately R2214 a month. Martins (2003) presents the MLL for an "average" family in a metropolitan area without specifying the size of such a household. When this MLL is adjusted to 2008 prices, the result is a MML of R2223 a month, which compares well to the Landman estimate. Both these MLLs are almost one and a half times the value of the FBS line.

One-dollar-a-day and two-dollar-a-day poverty lines are often utilised, especially in cases where analysts wish to make international comparisons. The one-dollar-a-day poverty line (based on its value in 2000 and updated to take into account the impact of inflation) yields a very low household poverty line of R529 in 2008 . This is

1 The BMR is university-based survey unit, which has been undertaking these measures since 1980. 
only about a third of the value of the FBS poverty line. The two-dollar-a-day line (adjusted for inflation) yields a household poverty line of R1058 in 2008, equivalent to about two-thirds of the FBS line.

\section{ESTIMATING A POVERTY LINE: AN APPLICATIONTO FREE BASIC MUNICIPAL SERVICES IN SOUTH AFRICA}

\section{TABLE 1: Comparison of Selected Poverty Lines for South Africa (in 2008 prices)}

\begin{tabular}{|c|c|c|c|c|c|}
\hline POVERTY LINE & $\begin{array}{c}\text { PER CAPITA } \\
\text { POVERTY LINE } \\
2008 \text { PRICES }\end{array}$ & $\begin{array}{l}\text { HOUSEHOLD } \\
\text { POVERTY LINE } \\
\text { (BASED ON } \\
\text { AVERAGE HH } \\
\text { SIZE OF 3.8) }\end{array}$ & $\begin{array}{l}\text { SHARE } \\
\text { OF FBS } \\
\text { POVERTY } \\
\text { LINE (ZM) } \\
\text { OF R1500 }\end{array}$ & NOTES & SOURCE \\
\hline MLL (1993) & R 429.28 & $\mathrm{R} 1,631.27$ & $109 \%$ & Calculated using the 1993 values & Woolard \& Leibbrandt (2001) \\
\hline SLL (1993) & R 575.42 & R 2,186.61 & $146 \%$ & Calculated using the 1993 values & Woolard \& Leibbrandt (2001) \\
\hline MLL & R 2,213.89 & R 2,213.89 & $148 \%$ & $\begin{array}{l}\text { MML for a household } \\
\text { of four people }\end{array}$ & Landman (2003) \\
\hline MLL & R 2,222.61 & R 2,222.61 & $148 \%$ & $\begin{array}{l}\text { Based on the MML for an average } \\
\text { family in a metropolitan area }\end{array}$ & Martins (2003) \\
\hline \$1 A DAY & R 139.20 & R 528.96 & $35 \%$ & $\$ 1$ a day & Hoogeveen \& Ozler (2006) \\
\hline \$2 A DAY & R 278.40 & R $1,057.92$ & $71 \%$ & $\$ 2$ a day & Hoogeveen \& Ozler (2006) \\
\hline $\begin{array}{l}\text { R322/COST OF } \\
\text { BASIC NEEDS }\end{array}$ & R 515.20 & R $1,957.76$ & $131 \%$ & $\begin{array}{l}\text { Cost of Basic Needs Approach - } \\
\text { Lower Bound line }\end{array}$ & Hoogeveen \& Ozler (2006) \\
\hline $\begin{array}{l}\text { R593/COST OF } \\
\text { BASIC NEEDS }\end{array}$ & R 948.80 & R $3,605.44$ & $240 \%$ & $\begin{array}{l}\text { Cost of Basic Needs Approach - } \\
\text { Upper Bound line }\end{array}$ & Hoogeveen \& Ozler (2006) \\
\hline
\end{tabular}

SOURCES: $\quad$ Woolard \& Leibbrandt (2001), Landman (2003), Martins (2003), Hoogeveen \& Ozler (2006); own calculations

Hoogeveen and Ozler (2006) estimate two poverty lines using the Cost of Basic Needs Approach. The point of departure is the daily energy requirement of 2261 kilocalories as recommended by the South African Medical Research Council (MRC), which is utilised to estimate the food component of the lines. The non-food component is estimated based on expenditure on essential non-food items (StatSA and National Treasury, 2007). As a result, two poverty lines are estimated, a lower bound line of R322 per capita in 2000 prices (R515.29 in 2008 prices) and R593 per capita in 2000 prices (R948.80 in 2008 prices). Adjusted for inflation and average household size, the R322 line yields a household poverty line of just less than R2000 in 2008. This is almost a third higher than the FBS poverty line. The upper bound line is R3605.44 per household in 2008, which is almost two-and-a-half times the value of the FBS line.

Ultimately the range of possible, although not all accurate, poverty lines for South Africa suggest that the FBS poverty line, in comparative terms, is low - with the exception of the $\$ 1$ a day and $\$ 2$ a day lines. Noting that these are more internationally benchmarked lines (rather than domestic, in-country poverty lines), it is evident that the FBS poverty line appears to be set significantly below any feasible poverty line for South Africa.

\section{FBS-COMPARABLE INDIGENT SUPPORT WITHIN GOVERNMENT}

The first decade of democracy has been characterised by a rapid widening and deepening of the state social security system. Social grants are targeted at the most vulnerable members of South African society, specifically the disabled, the aged and children. It has been widely accepted that the social security scheme of the government remains its most potent poverty reduction tool and in 2008 , the South African government 
announced further broadening of the social security net as part of its anti-poverty strategy. This included gradually equalising the qualifying age for the Old Age Pension (OAP) to 60 years for both men and women by the 2010/2011 financial year and extending the eligibility for the Child Support Grant (CSG) to the age of 15 by 2009 (National Treasury, 2008:92).

The vast expansion of the post-apartheid social security system is best illustrated by the increase in the number of grant beneficiaries since 1997. In 1997, just less than 3 million individuals received social grants, with more than half of this total accounted for by beneficiaries of the OAP. By April 2008, the total number of grant beneficiaries had increased to almost 12,4 million, corresponding to a growth rate of more than 300 percent. In February 2009, the National Treasury projected that by April of 2009, the number of beneficiaries would have increased by a further 1 million individuals to 13.4 million (National Treasury, 2008:95).

\section{TABLE 2: Social Grants Beneficiary Numbers by Type of Grant: 1997, 2008 and 2009}

\begin{tabular}{|l|r|r|r|r|}
\hline TYPE OF GRANT & AUGUST 1997 & APRIL 2008 & APRIL 2009 & \% OF TOTAL, 2009 \\
\hline OLD AGE GRANT & $1,742,253$ & $2,218,993$ & $2,324,615$ & 17.37 \\
\hline WAR VETERANS GRANT & 11,495 & 1,963 & 1,649 & 0.01 \\
\hline DISABILITY GRANT & 754,830 & $1,413,263$ & $1,404,884$ & 10.49 \\
\hline GRANT IN AID & 9,720 & 0 & 0 & 0.00 \\
\hline FOSTER CARE GRANT & 42,917 & 443,191 & 487,510 & 3.64 \\
\hline CARE DEPENDENCY GRANT & 3,815 & 101,836 & 105,909 & 0.79 \\
\hline CHILD SUPPORT GRANT & 400,599 & $8,195,524$ & $9,061,711$ & 67.69 \\
\hline TOTAL & $\mathbf{2 , 9 6 5 , 6 2 9}$ & $\mathbf{1 2 , 3 7 4 , 7 7 0}$ & $\mathbf{1 3 , 3 8 6 , 2 7 8}$ & $\mathbf{1 0 0 . 0 0}$ \\
\hline
\end{tabular}

SOURCE: Pauw \& Ncube (2007) calculated using data from National Treasury; National Treasury (2009)

NOTES: 1. The estimated number of beneficiaries for April 2009 is projected numbers provided by National Treasury in the 2009 Budget Review

2. The child support grant was introduced in 1998, the 1997 beneficiaries shown in the table therefore corresponds to the child maintenance grant

While the CSG is the most significant grant in terms of the number of beneficiaries, the monetary values of the OAP and the Disability Grant (DG) are the largest. On the $1^{\text {st }}$ of April 2009, the value of the OAP and the DG increased to R1010, while the value of the CSG increased to R240 (National Treasury, 2009:91).

All social grants are means-tested, meaning that there is some household income ceiling above which the grant will not be paid out. These thresholds differ for different grants and the threshold for adult grants depends on whether a single person or married couple resides in the household, with the threshold for a married couple generally double the ceiling for a single person (SASSA, 2009). An asset threshold is also applicable.

In May 2008, the threshold for the CSG increased to R2100 a month for rural households and R2200 a month for urban households. The income threshold for the OAP, DG and War Veterans Grant increased to R2244 a month for single people and R4488 a month for married couples (Moodley-lsaacs, 2008; SASSA, 2009). At the time of writing, the income thresholds for adult grants are R2426 a month for a single person and R4852 for a married couple, while the household income threshold for the CSG is now R2400 a month for both urban and rural areas (SASSA, 2009).

The table below illustrates the income thresholds utilised in the means tests for the CSG and the OAP in relation to the value of the FBS poverty line of R1500 a month. In 2008, both the rural and urban income thresholds used to determine eligibility for the CSG are almost one and half times the values of the FBS poverty line. The income threshold for qualification by a single person for an OAP is almost exactly one and 
a half times the household income level taken into account for the provision of free basic services, while the income threshold used to determine if two married people qualify for OAPs is almost three times the Rand value of the FBS poverty line.

\section{TABLE 3: Comparison of Income Thresholds for Social Grants and FBS Poverty Line, 2008}

\begin{tabular}{l|c|c|}
\hline & & \\
\hline & & \\
\hline CSG THRESHOLD - RURAL & SHARE OF FBS POVERTY LINE \\
\hline CSG THRESHOLD - URBAN & & $140 \%$ \\
\hline OAP THRESHOLD - SINGLE PERSON & $\mathrm{R} 2,200$ & $147 \%$ \\
\hline OAP THRESHOLD - MARRIED COUPLE & $\mathrm{R} 2,244$ & $150 \%$ \\
\hline
\end{tabular}

SOURCE: South African Social Security Agency (2009b); own calculations

To summarise then, all thresholds utilised in the means tests to determine eligibility for government support in the form of social grants are considerably higher than the FBS poverty line, ranging from about 1.4 times the FBS poverty line to three times that line in 2008 prices. This very initial comparison suggests that more households can be considered indigent or poor when using the means test income thresholds than when utilising the FBS poverty line.

\section{FREE BASIC SERVICES: ALTERNATIVE ESTIMATES OF COVERAGE IN 2008}

This section of the paper attempts to model, in a very basic manner, the potential number of households eligible for free basic services, assuming different potential values of a FBS poverty line, including the current line of R1500 per household per month. Specifically, the following lines will be considered:

- The FBS poverty line of R1500 a month, as well as two variations of this line, namely $50 \%$ of the FBS line (R750 a month) and double the value of the line (R3000 a month).

- An income level equal to two OAPs, which some municipalities use as threshold for indigent support (see PDG \& Isandla Institute, 2009; Erasibo, 2005). In 2008, this amounted to R1920 a month or 1.28 times the FBS poverty line

- The income threshold used to test for eligibly of urban households for the CSG. In 2008, this threshold was R2200 a month (or about one and a half times the FBS line).

- $\quad$ Finally, the income threshold used to evaluate eligibility for an OAP is utilised as a fifth potential poverty line. In this case the threshold for a household consisting of a married couple (R4488 a month) is used, which amounts to almost three times the FBS poverty line.

All poverty lines are in 2008 prices and the potential number of eligible households is estimated using total household expenditure from the 2005/06 IES, adjusted to 2008 prices $^{2}$. It should be noted that the number of potentially eligible households, however, is based on the estimates of total number of households in South Africa (12 457610 ) for 2005/06. The results are therefore only indicative, as the estimates cannot take into account any changes in the number of households or household expenditure between 2005/06 and 2008.

Table 4 presents the number and proportion of households eligible for free basic services when different estimates of a potential FBS line are utilised. Taking the current "official" FBS poverty line of R1500 a month as

2 It should be noted here that household size in not taken into account. Currently, when the "official" FBS poverty line is applied a household is considered eligible for free basic services simply if total household income is less than R1500 a month, irrespective of the number of people residing in that household. 
the point of departure, 29 percent or 3.61 million of all South African households qualify for free basic services. The rural/urban divide is clearly evident, with almost 45 percent of rural households and only approximately 21 percent of urban households considered indigent according to this line. In terms of the absolute number of households, about 1.93 million rural households live on less than R1500 a month, while 1.68 million urban households are considered poor. This means that 54 percent of poor households live in rural areas, while 46 percent live in urban areas (See Appendix 2 for the share breakdown of poor households according to location and province for the different poverty lines).

\section{TABLE 4: Number and Proportion of Households Eligible for FBS using Different Criteria}

\begin{tabular}{|c|c|c|c|c|c|c|c|c|c|c|c|c|}
\hline & \multicolumn{2}{|c|}{ R750/MONTH } & \multicolumn{2}{|c|}{ R1500/MONTH } & \multicolumn{2}{|c|}{ 2X OAP (R1920) } & \multicolumn{2}{|c|}{$\begin{array}{l}\text { CSG THRESHOLD } \\
\text { (R2200) }\end{array}$} & \multicolumn{2}{|c|}{ R3000/MONTH } & \multicolumn{2}{|c|}{$\begin{array}{l}\text { OAP THRESHOLD } \\
\text { (R4488) }\end{array}$} \\
\hline & NO OF HH & $\%$ & NO OF HH & $\%$ & NO OF HH & $\%$ & NO OF HH & $\%$ & NO OF HH & $\%$ & NO OF HH & $\%$ \\
\hline OUTH AF & & & & 29.00 & & 39.98 & & 45.96 & $7,250,063$ & 58.2 & 710,547 & 69.92 \\
\hline & & & & & & & & & & & & 03.03 \\
\hline & & 13.01 & & & & & & & & & & \\
\hline . & ,386 & & 1,007 & 15.81 & 288,862 & 22.72 & 349,607 & 27.50 & 488,122 & 38.39 & 623,985 & 49.07 \\
\hline 1 & 16,362 & 12.55 & 674,379 & 39.12 & 863,934 & 50.12 & 971,233 & 56.34 & $1,170,740$ & 67.92 & $1,343,068$ & 11.9 \\
\hline & & & & & & & & & & 65.17 & 223,363 & 76.16 \\
\hline TILL SIATL & & & & 30.60 & & & & 46.69 & & 59.06 & & 72.46 \\
\hline KWAZULU-NATAL & 171,393 & & 689,934 & 31.16 & 953,316 & 43.05 & $1,092,057$ & 49.32 & $1,397,136$ & 63.09 & $1,665,313$ & 75.20 \\
\hline NORTH WEST & & & 298,861 & 32.93 & & 46.49 & & 51.92 & & 63.07 & 676,019 & 74.50 \\
\hline GAUTENG & & & & & 829,213 & 27.94 & 993,377 & 33.47 & $1,337,669$ & 45.07 & $1,735,644$ & 58.48 \\
\hline MPUMALANGA & 104,843 & & 305,333 & 34.71 & 418,243 & 47.54 & 473,239 & 53.80 & 583,955 & 66.38 & 682,399 & 77.57 \\
\hline LIMPOPO & 139,204 & 10.70 & 525,008 & 40.37 & 696,758 & 53.58 & 803,557 & 61.79 & 977,916 & 75.20 & $1,109,231$ & 85.29 \\
\hline
\end{tabular}

SOURCE: Statistics South Africa (2008); own calculations.

NOTES: Households have been weighted using household weighs based on the 2001 Census

The provincial results show that the Western Cape and Gauteng can be considered relatively better off in terms of the share of households in these provinces spending less than R1500 a month. Only about 16 percent of Western Cape and 18 percent of Gauteng households qualify for free basic services. Limpopo can be considered the "poorest" province, with more than 40 percent of households spending less than R1500 a month. The share of households living on less than R1500 a month vary between 31 and 39 percent in the remaining provinces. The picture looks slightly different when the absolute numbers of poor households in the provinces are considered. The largest absolute number of households living below the FBS poverty line is found in KwaZulu Natal, with almost 700000 households poor according to this line. This province thus accounts for almost a fifth of indigent households in the country according to this measure.

The smallest absolute number of poor households is found in the sparsely populated Northern Cape, with less than 100000 households in this province qualifying for free basic services. It should be noted, however, that this corresponds to approximately a third of households living in this province. If half the value of the current FBS poverty line (R750 per household per month) is used to identify households eligible for free basic services, the total number of poor households in South Africa declines to less than a million (8 percent of all households). The urban poverty rate at this line is only 5 percent, while the rural poverty rate is 13 percent. These rates correspond to 433228 urban households and 565074 rural households respectively. 
Less than 3 percent of households in the Western Cape and just less than 5 percent of households in Gauteng live on less than R750 a month. At this line, household poverty is highest in the Eastern Cape, at 12.6 percent. This province also accounts for the largest absolute number of poor households $(216362)$. In the North West, Mpumalanga and Limpopo, the household poverty rates are above 10 percent at this line. While only 7.7 percent of households in KwaZulu-Natal are poor according to this line, this corresponds to more than 170 000 households.

The second alternative poverty line that we consider here is R1920 a month, which is twice the value of the OAP in 2008 prices. At this line the number of households qualifying for free basic services increases to just less than 5 million or almost 40 percent of all South African households. Approximately 2.6 million (51 percent) of these households live in rural areas, while 2.4 million (49 percent) live in urban areas.

At the R1920 a month line, the largest absolute number of households that qualifies for free basic services is found in KwaZulu-Natal, with 953316 households or 43 percent of all households in the province living below this line. The poverty rate, however, is highest in Limpopo, with almost 54 percent of households in the province poor according to this line. This corresponds to just fewer than 700000 households. Again, the household poverty rate is lowest in the Western Cape (about 23 percent), with the absolute number of poor households smallest in the Northern Cape at 133992.

In 2008, the income threshold used to determine eligibility for the CSG was R2200 a month per household in urban areas. According to our estimates, almost 46 percent of South African households or approximately 5.73 million households survive on less than that amount each month. The rural/urban split is almost fifty-fifty. The urban poverty rate, however, is only approximately 35 percent, while the rural poverty rate is 66 percent.

In KwaZulu-Natal, more than a million households qualify for free basic services, which constitute almost half of all households living in the province. At this line, the highest household poverty rate is, however, found in Limpopo, with almost 62 percent of households or just more than 800000 households living on less than R2200 a month.

When a potential poverty line twice the value of the current FBS line is considered, just more than 7.25 million or 58.2 percent of all households in South Africa qualify for free basic services. While the rural household poverty rate remains considerably higher than the urban rate, at this line the absolute number of households qualifying for free services becomes relatively higher in urban areas. Just more than 3.8 million, or 47 percent, of urban households live on less than R3000 a month. In contrast, almost 80 percent of rural households, or 3.44 million households, are considered poor when this line is utilised.

In three provinces, namely the Eastern Cape, KwaZulu-Natal and Gauteng, more than a million households spend less than R3000 a month. The poverty headcount rates are 68 percent for the Eastern Cape, 63 percent for KwaZulu-Natal and 45 percent for Gauteng. Limpopo remains the province with the highest headcount rate, with just more than three-quarters of households (approximately 980000 households) in the province living on less than R3000 a month.

The highest potential poverty line considered here is the income threshold used to test a married person's eligibility for the OAP. At this line of R4488 a month, almost 70 percent of South African households qualify for free basic services. This corresponds to 8.71 million households. While almost 90 percent of rural households and 60 percent of urban households are considered poor, there are almost a million more poor households in urban areas at this line.

The highest absolute number of poor households is found in Gauteng (1.74 million), with the province accounting for almost a fifth of all poor households in the country. Again the household headcount rate is highest in the Limpopo province, with more than 85 percent of households spending less than R4488 a month.

One of the key implications of adjusting the value of the FBS line relates to the total cost to the state of providing the package of free basic services. For example, by reducing the qualifying income threshold to only R750 a month, the state will "save" an amount equal to the cost of providing free basic services to approximately 2.61 million households. 


\section{TABLE 5: Number and Share of Households Eligible for FBS when using Different Poverty Lines: Comparison with FBS Poverty Line}

\begin{tabular}{|c|c|c|c|c|c|c|c|c|c|c|}
\hline & \multicolumn{2}{|c|}{ R750 - R1500 } & \multicolumn{2}{|c|}{ R1500 - R1920 } & \multicolumn{2}{|c|}{ R1500 - R2200 } & \multicolumn{2}{|c|}{ R1500 - R3000 } & \multicolumn{2}{|c|}{ R1500 - R4488 } \\
\hline & $\begin{array}{c}\text { CHANGE } \\
\text { IN } \\
\text { NO OF HH }\end{array}$ & $\begin{array}{l}\text { \% POINT } \\
\text { CHANGE }\end{array}$ & $\begin{array}{c}\text { CHANGE } \\
\text { IN } \\
\text { NO OF HH }\end{array}$ & $\begin{array}{l}\% \text { POINT } \\
\text { CHANGE }\end{array}$ & $\begin{array}{c}\text { CHANGE } \\
\text { IN } \\
\text { NO OF HH }\end{array}$ & $\begin{array}{l}\text { \% POINT } \\
\text { CHANGE }\end{array}$ & \begin{tabular}{|c|} 
CHANGE \\
IN \\
NO OF HH
\end{tabular} & $\begin{array}{l}\% \text { POINT } \\
\text { CHANGE }\end{array}$ & \begin{tabular}{|c|} 
CHANGE \\
IN \\
NO OF HH
\end{tabular} & $\begin{array}{l}\text { \% POINT } \\
\text { CHANGE }\end{array}$ \\
\hline SOUTH AFRICA & $2,613,920$ & 20.99 & $1,367,961$ & 10.98 & $2,113,819$ & 16.96 & $3,637,841$ & 29.20 & $5,098,325$ & 40.92 \\
\hline URBAN & $1,244,892$ & 15.35 & 745,583 & 9.19 & $1,169,794$ & 14.42 & $2,131,869$ & 26.27 & $3,164,182$ & 39.00 \\
\hline RURAL & $1,369,028$ & 31.50 & 622,378 & 14.33 & 944,025 & 21.73 & $1,505,972$ & 34.66 & $1,934,143$ & 44.52 \\
\hline WESTERN CAPE & 166,620 & 13.11 & 87,855 & 6.91 & 148,601 & 11.69 & 287,115 & 22.58 & 422,979 & 33.26 \\
\hline EASTERN CAPE & 458,017 & 26.57 & 189,556 & 11.00 & 296,855 & 17.22 & 496,361 & 28.80 & 668,689 & 38.79 \\
\hline NORTHERN CAPE & 71,941 & 24.53 & 35,982 & 12.26 & 53,979 & 18.40 & 93,135 & 31.75 & 125,353 & 42.74 \\
\hline FREE STATE & 210,303 & 23.39 & 98,825 & 10.99 & 144,696 & 16.09 & 255,871 & 28.46 & 376,378 & 41.86 \\
\hline KWAZULU-NATAL & 518,541 & 23.42 & 263,382 & 11.89 & 402,123 & 18.16 & 707,201 & 31.93 & 975,379 & 44.04 \\
\hline NORTH WEST & 205,212 & 22.61 & 123,029 & 13.56 & 172,275 & 18.99 & 273,501 & 30.14 & 377,158 & 41.57 \\
\hline GAUTENG & 396,993 & 13.38 & 284,671 & 9.59 & 448,835 & 15.12 & 793,127 & 26.72 & $1,191,101$ & 40.13 \\
\hline MPUMALANGA & 200,490 & 22.79 & 112,910 & 12.83 & 167,906 & 19.09 & 278,622 & 31.67 & 377,066 & 42.86 \\
\hline LIMPOPO & 385,804 & 29.67 & 171,751 & 13.21 & 278,550 & 21.42 & 452,908 & 34.83 & 584,223 & 44.92 \\
\hline
\end{tabular}

SOURCE: Statistics South Africa (2008); own calculations.

NOTES: $\quad$ The households have been weighted using household weighs based on the 2001 Census

On the other hand, by increasing the value of the FBS poverty line to R1920 a month, an additional 1.37 million households qualify for support in the form of free basic water, sanitation, electricity and refuse removal. If the FBS line is set at the value of the income threshold used in the means test in urban areas for the CSG (R2200 a month), the proportion of households qualifying for free basic services is almost 17 percentage points higher. This means that 2.11 million additional households will qualify for support.

Doubling the value of the FBS line to R3000 per household per month means that 3.64 million more households will qualify for free basic services than at present. Increasing the line further to the value of the income threshold for the OAP means test for a married person, results in more than five million additional households qualifying for support.

For all potential FBS poverty lines, the share of households that are poor is relatively larger in rural than in urban areas. At the highest alternative value of the FBS line, namely R4488 a month, the proportion of rural households living below that line is almost exactly double the share of rural households living below the current R1500 a month FBS poverty line. This means that an additional 1.93 million rural households qualify for free basic services.

Changing the level of the FBS poverty line has a relatively smaller impact on the share of urban households eligible for free basic services. These results, however, mask the fact that due to the relatively larger share of all South African households living in urban areas, each consecutive increase in the value of the potential FBS poverty line has a relatively larger impact in these areas when the additional absolute numbers of households that qualify for free basic services is considered.

A reduction of the current value of the FBS line to R750 a month will lead to a fifteen percentage point reduction in the proportion of urban households qualifying for free basic services from 20.7 to 5.3 percent. In addition, the absolute number of poor households declines by 1.24 million. 
If the FBS line is adjusted to the value of the income threshold for a married person to qualify for an OAP (thus our highest value of R4488 a month), urban municipalities will have to provide free services to an additional 3.16 million households. This represents an increase in the proportion of urban households qualifying for support of 39 percentage points.

The financial implications of the above are clear. Increasing the value of the FBS poverty line will have a much larger impact on urban municipalities than rural municipalities. If the FBS poverty line is increased to the highest potential amount suggested here - that is equal to the income threshold used to test a married person's eligibility for an OAP - about 1.93 million additional rural households qualify for free basic services. At the same line, more than 3 million additional urban households qualify for free basic services.

The results for provinces are also presented in Table 5. If a potential increase of the FBS poverty line to the highest alternative line of R4488 a month is considered, the share of poor households increases the most in Limpopo with almost 45 percentage points. This corresponds to 584223 additional households. The largest impact in terms of the additional absolute number of poor households is found in Gauteng, where an increase in the FBS poverty line to R4488 a month will result in 1.2 million additional households qualifying for free basic services.

\section{FISCAL IMPLICATIONS OF ALTERNATIVE ESTIMATES OF A FBS POVERTY LINE}

As alluded to above, increasing the number of households eligible for FBS has significant fiscal implications and in this section we attempt a very basic illustration of the financial impact of increasing the FBS poverty line.

Below we provide estimates of the differences in the total cost to the state, based on the number of households eligible for free basic services when different possible values of the FBS poverty line are utilised. These estimates have been calculated using the cost of providing the complete FBS package to households living in the City of Cape Town, according to estimates for the 2008/09 financial year published in the City's budget documentation. In order to arrive at the total cost per household of providing FBS, the cost of providing each service has been divided by the number of beneficiary households to provide an estimate of the unit cost of providing each specific service. The total cost per household is then simply the sum of the unit costs of each of the basic services (see Appendix 3 for the actual estimates). Appendix 4 provides the estimates of the total cost to the state to provide the FBS package when the alternative poverty lines are utilised. These estimates are again given for South Africa, as well as for urban and rural areas and for the nine provinces. It should be noted that the cost of providing free basic services differs vastly between municipalities, and the exercise here is just a very rudimentary illustration of the potential financial impact of adjusting the value of the FBS poverty line.

Tables 6 and 7 summarise the additional cost associated with the provision of FBS when higher poverty lines are utilised (or in the case of the R750/month line, the potential "savings" to the state). The estimates suggest that reducing the FBS poverty line to R750 a month per household will result in a "saving" of more than R3 billion at the aggregate level. On the other hand, if the FBS poverty line is increased to R4488 a month, municipalities will have to budget for an additional R6 billion to provide services to eligible households. This corresponds to an increase of more than 140 percent in the current budget (with the current budget being the total cost to provide free basic services when the R1500 FBS line is used to identify eligible households).

Previously, we have shown that increasing the value of the poverty line will not result in substantial increases in the number of rural households qualifying for free basic services. The evidence below shows that by increasing the poverty line to R1920 per household per month (twice the value of an OAP), the additional cost to the state will be about R743 million, or an increase of about 32 percent in the current budget for rural areas. If the highest of the potential poverty lines is utilised (R4488), the additional cost increases to R2.3 billion and the total budget, in fact, becomes double the current FBS budget for rural areas. 
TABLE 6: The Additional Cost Associated with Utilising Alternative FBS Poverty Lines

\begin{tabular}{|c|c|c|c|c|c|}
\hline & R750/MONTH & $2 X$ OAP (R1920) & $\begin{array}{l}\text { CSG THRESHOLD } \\
\text { (R2200) }\end{array}$ & R3000/MONTH & $\begin{array}{l}\text { OAP THRESHOLD } \\
\text { (R4488) }\end{array}$ \\
\hline SOUTH AFRICA & -R 3,118,406,620 & R $1,631,977,354$ & R 2,521,785,948 & R 4,339,944,194 & R 6,082,302,083 \\
\hline URBAN & -R 1,485,156,514 & R 889,479,923 & R $1,395,563,884$ & R 2,543,319,956 & R $3,774,869,484$ \\
\hline RURAL & -R 1,633,250,165 & R 742,496,954 & R $1,126,221,944$ & R 1,796,624,357 & R 2,307,432,599 \\
\hline WESTERN CAPE & -R 198,777,815 & R $104,810,931$ & R 177,280,826 & R $342,528,469$ & R $504,613,362$ \\
\hline EASTERN CAPE & -R 546,413,875 & R 226,139,831 & R $354,147,538$ & R $592,159,150$ & R $797,746,454$ \\
\hline NORTHERN CAPE & -R 85,825,386 & R 42,926,013 & R $64,397,341$ & R $111,110,329$ & R $149,545,723$ \\
\hline FREE STATE & -R 250,891,837 & R $117,898,619$ & R $172,621,743$ & R $305,253,566$ & R $449,018,668$ \\
\hline KWAZULU-NATAL & -R 618,619,723 & R 314,214,392 & R 479,732,751 & R $843,691,044$ & R 1,163,626,562 \\
\hline NORTH WEST & -R 244,818,000 & R $146,773,955$ & R 205,523,956 & R $326,286,097$ & R 449,949,375 \\
\hline GAUTENG & -R 473,612,184 & R $339,612,563$ & R $535,460,286$ & R $946,200,690$ & R $1,420,984,030$ \\
\hline MPUMALANGA & -R 239,184,117 & R $134,701,916$ & R 200,311,548 & R $332,395,748$ & R $449,840,144$ \\
\hline LIMPOPO & $-R \quad 460,263,695$ & R 204,898,585 & R 332,309,673 & R 540,319,244 & R $696,977,800$ \\
\hline
\end{tabular}

SOURCE: City of Cape Town (2009), Statistics South Africa (2008); Own calculations

In contrast, increasing the value of the FBS poverty line has a significantly larger financial impact in urban areas, particularly at the higher poverty line values. If the FBS line is increased to R1920 a month, the additional cost to urban municipalities will be around R890 million, which constitutes an increase of almost 45 percent in the cost of providing FBS. If the R4488 line is used to identify eligible households, the total cost of the provision of FBS to urban areas increases by almost R3.8 billion or by a massive 189 percent.

\section{TABLE 7: Percentage Increase (Decrease) in Total Cost Associated with Providing FBS when using Alternative Poverty Lines}

\begin{tabular}{l|c|c|c|c|c|} 
& R750/MONTH & 2X OAP (R1920) & $\begin{array}{c}\text { CSG THRESHOLD } \\
\text { (R2200) }\end{array}$ & R3000/MONTH & $\begin{array}{c}\text { OAP THRESHOLD } \\
\text { (R4488) }\end{array}$ \\
\hline SOUTH AFRICA & $-72.36 \%$ & $37.87 \%$ & $58.52 \%$ & $100.71 \%$ & $141.14 \%$ \\
\hline URBAN & $-74.18 \%$ & $44.43 \%$ & $69.71 \%$ & $127.04 \%$ & $188.56 \%$ \\
\hline RURAL & $-70.78 \%$ & $32.18 \%$ & $48.81 \%$ & $77.86 \%$ & $100.00 \%$ \\
\hline WESTERN CAPE & $-82.89 \%$ & $43.71 \%$ & $73.93 \%$ & $142.84 \%$ & $210.43 \%$ \\
\hline EASTERN CAPE & $-67.92 \%$ & $28.11 \%$ & $44.02 \%$ & $73.60 \%$ & $99.16 \%$ \\
\hline NORTHERN CAPE & $-73.40 \%$ & $36.71 \%$ & $55.08 \%$ & $95.03 \%$ & $127.90 \%$ \\
\hline FREE STATE & $-76.43 \%$ & $35.92 \%$ & $52.59 \%$ & $92.99 \%$ & $136.79 \%$ \\
\hline KWAZULU-NATAL & $-75.16 \%$ & $38.17 \%$ & $58.28 \%$ & $102.50 \%$ & $141.37 \%$ \\
\hline NORTH WEST & $-68.66 \%$ & $41.17 \%$ & $57.64 \%$ & $91.51 \%$ & $126.20 \%$ \\
\hline GAUTENG & $-72.90 \%$ & $52.28 \%$ & $82.42 \%$ & $145.65 \%$ & $218.73 \%$ \\
\hline MPUMALANGA & $-65.66 \%$ & $36.98 \%$ & $54.99 \%$ & $91.25 \%$ & $123.49 \%$ \\
\hline LIMPOPO & $-73.49 \%$ & $32.71 \%$ & $53.06 \%$ & $86.27 \%$ & $111.28 \%$ \\
\hline
\end{tabular}

SOURCE: City of Cape Town (2009), Statistics South Africa (2008); Own calculations 
The results according to province show that decreasing the value of the FBS poverty line to R750 a month will decrease the total cost of providing basic services by between 66 and 83 percent. In terms of actual Rand amounts, the biggest saving will occur in KwaZulu-Natal, where the total budget required to provide free basic services will decline by almost R620 million.

Increasing the value of the FBS poverty line will have the largest relative financial impact in Gauteng, followed by KwaZulu-Natal. If the FBS poverty line is set at R4488 a month, the total additional cost to municipalities in Gauteng to provide free basic services will be more than R1.4 billion - which constitutes a more than 200 percent increase in the current budget. The additional cost in KwaZulu-Natal will be almost R1.2 billion or a 140 percent increase in the current budget.

\section{POLICY RECOMMENDATIONS}

Many municipalities currently use a household income level of R1500 to identify households eligible for free basic services. This line is relatively low in comparison with other unofficial poverty lines, including the income thresholds used to evaluate eligibility for social grants. The evidence presented above illustrates that the share and number of households eligible for free basic services increases substantially when higher alternative FBS poverty lines are considered, including the income thresholds utilised in the means tests for social grants. This also suggests that while many households are not considered "poor enough" to qualify for free basic services, individuals living in these households do qualify for a social grant. This highlights the need for the development of a more consistent way of identifying households or individuals qualifying for government support in its different forms. More specifically, a standardised system of means testing should be introduced to identify households eligible for free basic services. This threshold should not only be standard across municipalities, but should also be more closely linked to the thresholds used by government to assess social grant beneficiaries.

Increasing the value of the FBS poverty line will, of course, have significant fiscal implications for the municipalities responsible for providing the free basic services. For example, if the FBS poverty line is set at the value of the income threshold used in the urban area means test for the CSG in 2008, more than 2 million additional households would qualify for support in comparison to the number of eligible households when the R1500 line is used. While a detailed investigation of alternative sources of revenue falls outside the ambit of this report, one possible policy option to consider is that of improving the targeting of free services to households who are considered indigent. Accurate empirical evidence is not available, but it does appear as if the policy is not implemented consistently across all municipalities. For example, the City of Cape Town provides free basic electricity to all domestic users which utilise less than $450 \mathrm{kWh}$ a month (City of Cape Town, 2011). The implication of this is that all users below that threshold receive free basic electricity, irrespective of their income level. One policy option is therefore to improve (and standardise) the targeting of free services to ensure that only those households genuinely considered indigent according to a FBS poverty line receive free basic services. The savings associated with better targeting can then be utilised for providing free services to more households (identified using a higher line than the current FBS line). However, targeting in itself can be costly and these costs will have to be considered.

To test the feasibility of the above, a pilot project can be introduced in selected municipalities to evaluate (1) the costs and savings associated with better targeting of free basic services and (2) the cost associated with increasing the FBS poverty line to be more comparable to other thresholds used to identify households or individuals eligible for other forms of government support.

\section{CONCLUSION}

The South African government has instituted a range of policy interventions in an attempt to improve the welfare of households in the country. One of the key (and most successful) interventions has been the increase in the delivery of public services to poor households, specifically local government's provision of a package of free basic services (FBS), consisting of free basic water, electricity, sanitation and refuse removal. It is, however, not completely clear how different municipalities identify the poor households which are eligible for these basic 
services. Evidence suggests that many municipalities currently consider all households with a total income of less than R1500 a month to be poor and therefore eligible for the FBS package. Currently, there is no official poverty line sanctioned by the South African government and when the FBS line is compared to the range of unofficial poverty lines used by policymakers and researchers, the evidence suggests that the FBS line of R1500 a month is significantly lower than any feasible poverty line for the country.

We therefore consider the impact of increasing the value of the FBS poverty line by, in a very basic manner, modelling the potential number of households covered when different values of the FBS poverty line (including the current R1500 a month line) are assumed. A lower variation of the line is also considered. As expected, the share and number of households which qualify for FBS increase with the application of higher potential values of the FBS poverty line, irrespective of province and settlement. In addition, the proportion of households qualifying for free basic services remains higher in rural areas, and in provinces with a relatively large concentration of households living in rural areas, such as the Eastern Cape, KwaZulu Natal and Limpopo. When the absolute number of households qualifying for FBS at the alternative poverty lines is considered, the picture looks slightly different. The absolute number of households in urban areas eligible for FBS increases by a much larger magnitude with each increase in the value of the potential poverty line.

This, of course, also has financial implications for the municipalities providing these services. At the aggregate level, the cost of providing FBS to the additional number of eligible households, varies from R1.63 billion when twice the value of an Old Age Pension is used as the poverty line (R1920), to more than R6 billion when the highest alternative value here (namely R4488 which corresponds to the income threshold to test a married persons eligibility for an Old Age Pension) is utilised.

Urban municipalities will face the steepest increases in their FBS budgets, with the aggregate additional expenditure varying from R889.5 million when the R1920 line is utilised to R3.78 billion when the R4488 line is utilised. The additional expenditure in rural areas varies from R742.5 million to R2.3 billion.

The key policy recommendations include the need for the development of a standard poverty line or income threshold to identify households eligible for government support, as well as the need to assess how to best finance the provision of FBS to larger numbers of households. 


\section{REFERENCES}

Bureau for Market Research, 2002. Minimum and Supplemental Living Levels in the Main and Other Selected Urban Areas of the Republic of South Africa. Research Report No. 307. University of South Africa, Pretoria.

Chaudhuri, S and Ravallion, M, 1994. How well do static welfare indicators identify the chronically poor? Journal of Public Economics 53(3), pp. 367-394.

City of Cape Town, 2009. Draft Budget 2009/2010 to 2011/2012. http://www.capetown.gov.za/en/ Budget/Documents/Budget\%202009-2010\%20final/0910_Budget_May09CouncilSubmission_ IncludingReplacementPages.pdf Accessed 23 November 2009.

City of Cape Town, 2011. City of Cape Town Budget 2011/12 to 2013/14. http://www.capetown.gov.za/en/ Budget/Documents/Budget\%202011-\%202012\%20Draft/1112\%20Budget_ForTablingAtCouncil_Feb11_S. pdf Accessed May 2011.

Deaton, A, 1997. The Analysis of Household Surveys: A Microeconometric Approach to Development Policy. Johns Hopkins Press, Baltimore.

Erasibo (Pty) Ltd, 2005. Guidelines for the Implementation of the National Indigent Policy by Municipalities. Draft Document \#1, Limited release. Prepared for the Department: Provincial and Local Government: Republic of South Africa. Johannesburg, November 2005. http://fbs.dplg.gov.za/fbs/site/ docs/DocumentLibrary/IP/Guidelines.pdf?PHPSESSID=013091d9aefa4e755a8a3381fff69d11 Accessed November 2009.

Hoogeveen, JG \& Ozler, B, 2006. Poverty and Inequality in Post-apartheid South Africa: 1995-2000. In Bhorat, H \& Kanbur, R (Eds), Poverty and Policy in Post-Apartheid South Africa. pp. 59-94. HSRC Press, Cape Town.

Landman, JP, 2003. Breaking the Grip of Poverty and Inequality in South Africa 2004-2014: Current trends, issues and future policy options. Executive Summary Coordinated by J.P. Landman. http://www.nu.ac.za/ ccs/files/P661-Povertyreport3b.pdf Accessed 29 October 2009.

Martins, JH, 2003. Minimum Living Level and Consumer Price Index: what's in a name? Development Southern Africa. 20(2), pp. 197-212. http://www.informaworld.com/smpp/content db=all?conte $\mathrm{nt}=10.1080 / 03768350302954$. Accessed September 2009.

Moodley-Isaacs, N, 2008. More people to get grants after means test is adjusted. Personal Finance, 31 May. http://www.persfin.co.za/general/print_article.php?fArticleld=4431780\&fSectionld=596\&fSetld=300 Accessed 30 October 2009.

National Treasury, 2008. 2008 Budget Review. http://www.treasury.gov.za/documents/national\%20 budget/2008/review/Default.aspx Accessed 30 October 2009.

National Treasury, 2009. 2009 Budget Review. http://www.treasury.gov.za/documents/national\%20 budget/2009/review/default.aspx Accessed 30 October 2009.

Oosthuizen, M, 2008. Estimating Poverty Lines for South Africa. Unpublished Research Report, Development Policy Research Unit, University of Cape Town, Cape Town.

Pauw, K \& Mncube, L, 2007. Expanding the Social Security Net in South Africa: Opportunities, Challenges and Constraints. Development Policy Research Unit Working Paper 07/127. University of Cape Town, Cape Town.

PDG \& Isandla Institute, 2009. Municipal rates policies and the urban poor - how can municipal rates policies promote access by the poor to urban land markets? Report prepared for SA Cities Network and Urban LandMark. http://www.urbanlandmark.org.za/downloads/municipal_rates_policies_urban_poor.pdf Accessed 16 November 2009. 
Ravallion, M, 1992. Poverty Comparisons: A Guide to Concepts and Methods. LSMS Working Paper, No. 88. The World Bank, Washington DC. http://www.worldbank.org/LSMS/research/wp/wp_title.html. Accessed 25 January 2007.

South African Social Security Agency, 2009. About Social Grants: Means Test. http://www.sassa.gov.za/ content.asp?id=1000000510 Accessed 20 November 2009.

Statistics South Africa and National Treasury, 2007. A National Poverty Line for South Africa. http://www. treasury.gov.za/publications/other/povertyline/Treasury\%20StatsSA\%20poverty\%20line\%20discussion\%20 paper.pdf Accessed 30 October 2009.

Statistics South Africa, 2008. Income and Expenditure Survey 2005/2006. Dataset.

Woolard, I \& Leibbrandt, M, 2001. Measuring Poverty in South Africa. In Bhorat, H et al (Eds.) Fighting Poverty: Labour Markets and Inequality in South Africa. pp. 41-73. UCT Press, Cape Town.

Woolard, I \& Leibbrandt, M, 2006. Towards a Poverty Line for South Africa: A Background Note. http://www.treasury.gov.za/publications/other/povertyline/Woolard\%20Murray\%202005\%20Towards\%20 a\%20Poverty\%20Line.pdf. Accessed 30 October 2009. 


\begin{tabular}{|c|c|c|c|c|c|c|c|}
\hline POVERTY LINE & 1993 PRICES & 2000 PRICES & 2004 & MARCH 2006 & $\begin{array}{l}\text { PER CAPITA } \\
\text { POVERTY LINE } \\
2008 \text { PRICES }\end{array}$ & $\begin{array}{l}\text { HOUSEHOLD } \\
\text { POVERTY LINE } \\
\text { (BASED ON } \\
\text { AVERAGE HH } \\
\text { SIZE OF 3.8) }\end{array}$ & $\begin{array}{l}\text { SHARE } \\
\text { OF "FBS" } \\
\text { POVERTY } \\
\text { LINE OF } \\
\text { R1500 }\end{array}$ \\
\hline $\begin{array}{l}\text { MINIMUM LIVING LEVEL } \\
\text { (PER CAPITA) }\end{array}$ & R 164.20 & & & R 352.01 & R 429.28 & R $1,631.27$ & $109 \%$ \\
\hline $\begin{array}{l}\text { SUPPLEMENTAL LIVING } \\
\text { LEVEL (PER CAPITA) }\end{array}$ & R 220.10 & & & R 471.85 & R 575.42 & R 2,186.61 & $146 \%$ \\
\hline MLL & & & R 1,713 & & R 2,213.89 & R 2,213.89 & $148 \%$ \\
\hline MINIMUM LIVING LEVELS & & R $1,389.13$ & & R $1,822.54$ & R 2,222.61 & R 2,222.61 & $148 \%$ \\
\hline $\begin{array}{l}\text { PER ADULT EQUIVALENT } \\
\text { HH SUBSISTENCE LEVEL }\end{array}$ & R 251.10 & & & & R 656.47 & R 2,494.59 & $166 \%$ \\
\hline \$1 A DAY & & R 87 & & R 114.14 & R 139.20 & R 528.96 & $35 \%$ \\
\hline \$2 A DAY & & R 174 & & R 228.29 & R 278.40 & R 1,057.92 & $71 \%$ \\
\hline $\begin{array}{l}\text { R322/COST OF BASIC } \\
\text { NEEDS }\end{array}$ & & R 322 & & R 422.46 & R 515.20 & R $1,957.76$ & $131 \%$ \\
\hline $\begin{array}{l}\text { R593/COST OF BASIC } \\
\text { NEEDS }\end{array}$ & & R 593 & & R 778.02 & R $1,020.76$ & R 3,878.88 & $259 \%$ \\
\hline
\end{tabular}

SOURCES: $\quad$ Woolard \& Leibbrandt (2001), Landman (2003), Martins (2003), Hoogeveen \& Ozler (2006); own calculations

\section{APPENDIX 2: Breakdown of Poor Households by Location, using Different Poverty Lines}

\begin{tabular}{l|c|c|c|c|c|c|} 
& R750/MONTH & R1500/MONTH & $\begin{array}{c}\text { 2X OAP } \\
\text { (R1920) }\end{array}$ & $\begin{array}{c}\text { CSG } \\
\text { THRSHOLD } \\
\text { (R2200) }\end{array}$ & R3000/MONTH & $\begin{array}{c}\text { OAPTHRSHOLD } \\
\text { (R4488) }\end{array}$ \\
\hline SOUTH AFRICA & $100.00 \%$ & $100.00 \%$ & $100.00 \%$ & $100.00 \%$ & $100.00 \%$ & $100.00 \%$ \\
\hline URBAN & $43.40 \%$ & $46.46 \%$ & $48.67 \%$ & $49.74 \%$ & $52.55 \%$ & $55.59 \%$ \\
\hline RURAL & $56.60 \%$ & $53.54 \%$ & $51.33 \%$ & $50.26 \%$ & $47.45 \%$ & $44.41 \%$ \\
\hline WESTERN CAPE & $3.44 \%$ & $5.56 \%$ & $5.80 \%$ & $6.11 \%$ & $6.73 \%$ & $7.16 \%$ \\
\hline EASTERN CAPE & $21.67 \%$ & $18.67 \%$ & $17.35 \%$ & $16.96 \%$ & $16.15 \%$ & $15.42 \%$ \\
\hline NORTHERN CAPE & $2.61 \%$ & $2.71 \%$ & $2.69 \%$ & $2.65 \%$ & $2.64 \%$ & $2.56 \%$ \\
\hline FREE STATE & $6.50 \%$ & $7.62 \%$ & $7.51 \%$ & $7.33 \%$ & $7.32 \%$ & $7.48 \%$ \\
\hline KWAZULU-NATAL & $17.17 \%$ & $19.10 \%$ & $19.14 \%$ & $19.07 \%$ & $19.27 \%$ & $19.12 \%$ \\
\hline NORTH WEST & $9.38 \%$ & $8.27 \%$ & $8.47 \%$ & $8.23 \%$ & $7.89 \%$ & $7.76 \%$ \\
\hline GAUTENG & $14.78 \%$ & $15.07 \%$ & $16.65 \%$ & $17.35 \%$ & $18.45 \%$ & $19.93 \%$ \\
\hline MPUMALANGA & $10.50 \%$ & $8.45 \%$ & $8.40 \%$ & $8.26 \%$ & $8.05 \%$ & $7.83 \%$ \\
\hline LIMPOPO & $13.94 \%$ & $14.53 \%$ & $13.99 \%$ & $14.03 \%$ & $13.49 \%$ & $12.73 \%$ \\
\hline
\end{tabular}

Source: Statistics South Africa (2008); own calculations.

Notes: $\quad$ The households have been weighted using household weighs based on the 2001 Census 


\section{APPENDIX 3: Estimated cost of providing free basic services to households in City of Cape Town, 2008/09}

\begin{tabular}{l|c|c|c|} 
& NUMBER OF HH RECEIVING FBS & COST OF FBS PROVIDED & COST PER HH \\
\hline WATER & 847,000 & $\mathrm{R} 259,814,000$ & $\mathrm{R} 306.75$ \\
\hline SANITATION & 811,000 & $\mathrm{R} 154,278,000$ & $\mathrm{R} 190.23$ \\
\hline ELECTRICITY & 424,000 & $\mathrm{R} 135,834,000$ & $\mathrm{R} 320.36$ \\
\hline REFUSE & 477,000 & $\mathrm{R} 179,333,000$ & $\mathrm{R} 375.96$ \\
\hline COST PER HH OF PROVISION OF FBS & & $\mathrm{R} \mathbf{1 , 1 9 3 . 3 0}$
\end{tabular}

Source: City of Cape Town (2009); Own calculations

\section{APPENDIX 4: Cost of the Provision of FBS when utilising Alternative FBS Poverty Lines}

\begin{tabular}{|c|c|c|c|c|c|c|}
\hline & R750/MONTH & R1500/MONTH & 2X OAP (R1920) & $\begin{array}{l}\text { CSG THRESHOLD } \\
(\mathbf{R} 2200)\end{array}$ & R3000/MONTH & $\begin{array}{l}\text { OAP THRESHOLD } \\
\text { (R4488) }\end{array}$ \\
\hline & NO OF HH & NO OF HH & NO OF HH & NO OF HH & NO OF HH & NO OF HH \\
\hline SOUTH AFRICA & R 1,190,974,346 & R 4,309,380,965 & R $5,941,358,319$ & R 6,831,166,913 & R 8,649,325,159 & R $10,391,683,048$ \\
\hline URBAN & R $516,840,527$ & R 2,001,997,041 & R 2,891,476,963 & R $3,397,560,925$ & R 4,545,316,996 & R $5,776,866,525$ \\
\hline RURAL & R $674,133,759$ & R 2,307,383,925 & R $3,049,880,879$ & R $3,433,605,869$ & R 4,104,008,282 & R 4,614,816,524 \\
\hline WESTERN CAPE & R $41,023,023$ & R 239,800,838 & R $344,611,770$ & R $417,081,664$ & R 582,329,307 & R $744,414,200$ \\
\hline EASTERN CAPE & R $258,120,033$ & R $804,533,908$ & R $1,030,673,739$ & R $1,158,681,446$ & R 1,396,693,059 & R 1,602,280,363 \\
\hline $\begin{array}{l}\text { NORTHERN } \\
\text { CAPE }\end{array}$ & R $31,100,830$ & R 116,926,216 & R $159,852,229$ & R $181,323,557$ & R 228,036,546 & R $266,471,940$ \\
\hline FREE STATE & R $77,360,371$ & R $328,252,208$ & R $446,150,827$ & R $500,873,952$ & R $633,505,774$ & R $777,270,876$ \\
\hline KWAZULU-NATAL & R $204,472,004$ & R 823,091,727 & R $1,137,306,119$ & R 1,302,824,478 & R $1,666,782,771$ & R $1,986,718,290$ \\
\hline NORTH WEST & R $111,723,293$ & R $356,541,292$ & R $503,315,247$ & R $562,065,248$ & R $682,827,389$ & R 806,490,667 \\
\hline GAUTENG & R 176,026,482 & R 649,638,666 & R 989,251,228 & R 1,185,098,952 & R 1,595,839,356 & R 2,070,622,696 \\
\hline MPUMALANGA & R 125,077,866 & R $364,261,983$ & R 498,963,899 & R $564,573,531$ & R $696,657,730$ & R $814,102,126$ \\
\hline LIMPOPO & R 166,070,491 & R 626,334,186 & R 831,232,771 & R 958,643,859 & R $1,166,653,430$ & R 1,323,311,987 \\
\hline
\end{tabular}

Source: City of Cape Town (2009), Statistics South Africa (2008); Own calculations 